Journal of Life Economics

Cilt / Volume 7, Sayı / Issue 1, 2020, pp. 59-78

E - ISSN: 2148-4139

URL: https://www.ratingacademy.com.tr/ojs/index.php/jlecon

DOİ: https://doi.org/10.15637/jlecon.7.005

Araştırma Makalesi/Research Article

\title{
ISTANBUL HOUSING AND LAND APPRAISAL SYSTEM REFORM DEVELOPMENT PROCESS AND PROPERTY VALUES ANALYSIS
}

\author{
Pelin YİĞİT * \\ * Dr. $\ddot{O} \breve{g r}$. Üyesi, Nişantaşı University, Faculty of Engineering and Architecture, \\ TURKEY, e-mail: pelin.yigit@nisantasi.edu.tr \\ ORCID ID: https://orcid.org/0000-0003-2473-7157
}

Geliş Tarihi: 16 Aralık 2019; Kabul Tarihi: 28 Ocak 2020

Received: 16 December 2019; Accepted: 28 January 2020

\begin{abstract}
One of the main problems of developing countries is having difficulties in finding sources for housing finance. In order to solve housing finance problems of a country, institutional systems that have been structured according to its own economic and social conditions should be applied by the government. The main purpose of this study is to determine an appropriate housing finance development designed based on Turkey's current conditions. In this study, the location of the construction sector in Turkey's economy, development of real estate sector in Turkey, the embryonic period of the housing market, development of criteria and indicators in the housing sector reform in the housing system were investigated. The construction sector is a so-called locomotive instruction of the economy. Turkey in the building industry as one of the economies in this category, especially after the 1980s and is growing constantly evolving. Today, the real estate sector has entered a rapid development process. Importance has been given to user needs in the projects produced and marketability has started to be seen as one of the most important factors of project success. For the solution of the housing problem, all the legal and operational measures taken by the state and the priorities determined are called housing policy. If the housing policy concept is to be examined, how the housing becomes a field of policy-making, how housing policies manifest in developed and underdeveloped countries or the problems encountered in its formation and performance can be studied and explored separately. Housing problems, housing policy and examine engagaments held in Turkey on a private housing finance field are reached some conclusions. The first one is the fact that the housing problem is a dynamic structure and may vary periodically in Turkey as it is in the world due to changes in demographic structure, stock depreciation and migration. Second, it is compulsory that the issue of housing as an economic asset increases with the globalization of the world, and that it is necessary to address this issue more carefully in countries that are in the process of transition to global economic integration. Third, the rapid population growth in Turkey (albeit with a relatively slow) will continue in the coming 20-year period together with urbanization, especially the aging of the stocks that make up the majority mania apartment blocks began in 1950-1960's year, worn with together will increase the destruction. A housing policy that is designed with these principles in mind; Financial Interventions to be carried out on housing investments, taxes, loans, housing purchase methods and similar areas, rent control and condominium applications, legal
\end{abstract}


interventions to be carried out on various legal restrictions and incentives and housing standards, housing production types, construction methods and building materials technical interventions. At the end of this study, it is understood that housing finance model based on mortgage backed securities can be applied in the near future in Turkey. However, there are some requirements and regulatory needs must be fulfilled in many fields, such as in law of bankruptcy, tax regulations, law of banking and leasing, capital markets, and real- estate appraisal applications.

Keywords: Developing countries, housing policy, housing problem, design, architecture, real estate, capital markets, urbanization.

Jel Codes: A10, B41, D40, K10, O20

\section{INTRODUCTION}

The construction sector is of critical importance for our economy in terms of the added value it creates, its share in GDP, the high employment potential, the weight of national capital, the number and diversity of the sectors it interacts with, as well as the contributions it creates through its overseas contracting services. In this study, the structural analysis of the sector within the framework of international competitiveness is aimed.

The construction sector, which has a GDP share in the range of 5-6.5 percent on an annual basis, interacts with many sectors with input-output. While the sector employment shows seasonal fluctuations, it approaches 1.9 million in summer months and the overall employment share of the sector is between 5-7 percent. The employment of the sector extends to a broad base in terms of both flat labor, intermediate labor force and qualified labor force. The sector also contributes to our economy in terms of foreign exchange inflow and technology transfer through its overseas contracting services.

The construction sector is an important economic activity and opportunity area for our country in addition to its potential in the country. The Turkish overseas contracting services sector, which has undertaken an increasing volume of international commitments in recent years, has an important potential in terms of development and competitiveness of our country, and it is necessary to identify new strategies for the long-term survival of the sector in the global competitive environment. Since the contracting services sector mainly produces services in line with the demand of the construction sector, these two sectors need to be evaluated as a whole. Therefore, structural analysis of the construction sector within the framework of international competitiveness and determination of its strengths and weaknesses will also contribute to the development of strategies for foreign contracting services.

The construction sector is a so-called locomotive instruction of the economy. This attachment is due to the added value created by the sector especially during economic growth periods, employment potential and the input-output relationship with many sectors. The sector's direct share in GDP has changed between 5.4 percent and 6.5 percent annually in the last 10 years.

In this study, the location of the construction sector in Turkey's economy, development of real estate sector in Turkey, the embryonic period of the housing market, development of criteria and indicators in the housing sector reform in the housing system were investigated. 


\section{TURKEY CONSTRUCTION SECTOR ROLE IN ECONOMY}

In empirical studies conducted in order to determine the relationship between the investment expenditures in the construction sector and the economic growth in the developing countries, it is observed that the investment expenditures in the construction sector generally nourish the economic growth and increase the economic growth rate.

In these countries, construction sector industrial buildings to houses; from energy facilities to public infrastructure investments.

Turkey in the building industry as one of the economies in this category, especially after the 1980s and is growing constantly evolving.

Considering the period after 2000 as an accumulation of this growth and development trend in the sector, it is seen that a significant portion of the increase in GDP is nourished by the growth in the construction industry and the construction expenditures of both the public and private sector have increased. However, the crisis in February 2001, although it started as a currency and banking crisis, has spread rapidly to all sectors including the construction sector and has turned into a deep economic crisis.

As a matter of fact, the economy shrank by $3.4 \%$ in 1999 compared to the previous year, it grew by $6.8 \%$ in 2000 , and in 2001 , with a shrinkage of $5.7 \%$, it started to shrink again. In 2002 , the economic growth, which had a positive trend of $6.2 \%$, continued until the last quarter of 2008. The economy, which had contracted for four consecutive quarters since then, has again entered a period of growth.

Parallel to this economic growth and recovery process, the share of the construction sector in GDP also increased after 2001. The continuous and volatile growth process in the Turkish construction sector between 2002 and 2007 reached its peak with $18.5 \%$ in 2006. In 2007 , the decline in housing demand, the general election period, economic and political uncertainties affected the construction sector's recession.

As mentioned earlier, economic uncertainty and the construction industry from the beginning of the sectors affected negatively from the contraction that occurred in 2008 and Turkey as well as into the area of impact of the global crisis has once again entered a recession period. Accordingly, the beginning of 2009 with the expectation of crisis negatively affected the construction sector and the sector experienced a sharp contraction of $16.1 \%$. In the first quarter of 2010, the growth in GDP was $12 \%$, while the construction sector increased by $8.3 \%$. On the other hand, in the second, third and fourth quarters, it was observed that the sector was on the way to recovery with $20.4 \%, 22.1 \%$ and $17.5 \%$ growth performance.

In parallel with this, GDP grew by $8.9 \%$ in the year 2010 following the crisis period. The growth of the construction sector, which is composed of public and private sector construction investments, was realized as $17.1 \%$.

The annual growth rates of the construction sector and GDP are given in Figure 1 in order to see the extent to which the construction sector is following a parallel course with GDP.

As can be seen from Figure 1, there is a similar trend between economic growth and the growth rate of construction sector in general.

Turkey's economy in 1999 and 2001 and in parallel with the growth rate of economic contraction in the construction sector which has experienced various reasons in 2009 has also decreased markedly. 


\section{HOUSING MARKET DEVELOPMENT PROCESS IN TURKEY}

One of the most basic needs of people, which provides physical shelter is the physical and moral spaces that together keep the family as the basic unit of society. The settlement is a social process as well as meeting the need for accommodation.

The transition to industrial society, the development of land and railway transportation accelerated the relations of the people living in the rural areas and those living in the city. The process of migration and urbanization, which started with the industrial revolution and increased with the mechanization process in agriculture after the World War II, brought about the problem of very rapid housing production.

In this period, where sufficient land and housing offerings could not be provided, the unlawful housing presentation forms were also made to be accepted to some extent, and shortly, licensed and unlicensed housing presentations were realized.

In addition to the build-seller housing presentation, the shantytown process continued rapidly. In the 1960s, the housing presentation method could not be solved by the cooperatives that emerged in the 1960s. In all these developments, the quality element was not given importance in the presentation of the constructor, shanty and cooperative housing.

After 1965, production and slum production gained momentum. These forms of presentation have created cities with high density and significant problems.

The problem of housing has grown, and in the 1970s gradually forms of public housing have begun to emerge. However, they have not been institutionalized and the cooperatives have become the most important housing manufacturer.

Today, the real estate sector has entered a rapid development process. Importance has been given to user needs in the projects produced and marketability has started to be seen as one of the most important factors of project success.

Residential development projects in Turkey can be grouped as follows:

- Villas / Row Houses

- Apartment / Mass Housing Projects, Satellite Cities

- Multi-storey Residence Projects

Nowadays, the housing user has become more conscious. Quality, security, earthquake resistance, social facilities, reliability. conditions

\section{EMBRYONIC PERIOD OF HOUSING MARKET}

\subsection{After the Establishment of the Republic, Slow Urbanization, 1923-1950}

The first period, the establishment of the Republic of Turkey until the end of World War 2 covers the last time.

Although Turkey, 2. if he enters World War 2 War of Independence and in this process can be seen as the process of building a state employee for restructuring in World War II.

The most important issues that the state should consider in relation to the housing structuring of the period are the reconstruction and housing problem of the cities that emerged from the War of Independence.

In other words, the producer / investor who has a say in the housing production of the period is the state itself. 
However, there are not many residences produced for a large number of users in the period until the 1930s; re-use of existing houses, rather than new housing production, is foreseen.

The housing produced by the state between 1925-34 is mostly used by the public institutions in the new capital Ankara and for the use of state employees.

Even though the state had tried to solve the planning and housing problem by various laws until the 1930s, the state could not become an active actor in housing production due to the lack of adequate capital and lack of organization. Housing practices are mostly on the basis of individual dwellings or apartment buildings produced by individuals for their own use. These dwellings are the houses that the middle and mostly upper income groups are able to have a plot of land to accommodate themselves and their families.

The individual who owns the land realizes the housing production as a projector and implementer. The dwellings are mostly single houses with low density, garden produced for their own use. In addition to single houses, individual apartments were also built in urban centers with individual production. In these apartments, the owner is the owner of the land. The apartments, which are designed for the use of the family members of the landowner, can be used by renting by the people who have regular income to meet the rent of a house.

In short, until the 30s, the owner of the land, which is the housing production / investor, tries to solve the housing problem by building a low-density single house or apartment.

At this point, it would not be wrong to say that the role of the architect in designing the individual produced dwellings is great.

The owner of the land, who wants to acquire housing for his own use, produces houses by taking advantage of the expertise of the architect. In addition to the purpose of use, this middle upper income group, which owns the single house, uses the dwelling as a prestige and prestige for the residence it will use. It is a process that gains value through the wishes of the user and the design created by the architect, and therefore individual production can be defined as a process where the architect is actively involved, and the private and private workplaces are designed.

In the 1940s, state-owned employees are working to acquire housing. The realization of the state bank, Emlak Eytam Bank, to support the construction of housing for state employees and to start housing loans with the condition of co-operative partnership of SSK established in 1945 , as well as the planning of housing production forms and housing presentation forms, as well as small scale housing production. has become one of the issues of interest to the state.

With the increase in the demand for housing in the cities and the limited production of the houses, the public sector began to establish co-operatives. In the form of this housing presentation, the producer / investor is not the state, but the private sector, but it is supported by the public institutions in terms of the process of operation or finance.

The housing co-operative primarily addressed the employees of the state with a regular income in the upper income group - a small portion of the segment demanding the citizen. After the mid-40s, the state focused on the creation of housing cooperatives in Anatolia for lowincome groups such as workers and civil servants. In this period he continued to be implemented by private investors after the melt co-operator housing 50 carried by state aid in various socioeconomic users in various places in Turkey for mike status. The attitude of the architect in the production process of labor houses and housing cooperatives varies according to the individual housing production. 
The views of the architects of the period show that the architects interpret the issue on the principle of populism (Sey 1998). Thus, the state workers and cooperative houses that are produced gain value through the original design of the architect based on the values of the userbased, the environment and culture. Towards the '50s, architects can be said to have moved away from local values by being influenced by Western modernism (Sey 1998). The establishment of a new state and the discourses of creating contemporary and modern built environments overlap with each other, so that the houses began to be read through the values of modern architecture.

It is understood that the first forms of presentation were limited to single houses, single flats, workers houses, or houses built by the co-operatives. The construction process continued with low density with individual parties and housing co-operatives.

Although the population accumulation in the cities started to increase towards the end of the period, the urbanization rate was slow due to the use of the existing housing stock in general, and the low density progressive housing production through housing construction in urban areas only.

However, the housing production process, which started at a relatively low density during the period and did not progress rapidly, gained a different dimension with the emergence of new housing presentation forms such as the slums towards the end of the period.

\subsubsection{Fast and unplanned urbanization after migration, 1950-1980}

In the period after 1950, there are two important events affecting the housing production and presentation formats in Turkey. The first is that the economic stagnation experienced during World War II gained a different dimension with the end of the war. In fact, all post-war world which is effective mechanization and industrialization of agricultural production and the result of the depreciation of the transition to a market economy in Turkey have also followed a similar path.

Mechanization in agriculture left the agricultural worker living in Anatolia unemployed and the unemployed found the remedy to migrate to the cities. Thus, there has been a great increase in the urban population. This increase can also be easily followed by figures; while the population growth in cities was $20.1 \%$ between 1940-50, it increased by 4 times between 195060 and became $80.2 \%$.

Thus, in the previous period, new urban residents who came to the city dwellings who were not able to meet the demand for housing with the forms of production implemented in the previous period. Until the 1950s, there was no production for the lower income group, except for the housing produced for workers and civil servants. This problem is mostly the problem of the new urban people who come to the city after migration and do not have a regular income. The solutions created by the problem define the first break, in other words, the inclusion of new actors producing a new housing presentation form, the shanty house and the slum. (Tekeli 1982).

This new housing presentation style, which is mostly directed to the lower income group with no regular income, is the shanty houses, which have been implemented by the user at the beginning and which have been applied by the user. These dwellings, which are built for use only, have been rapidly growing and creating squatter neighborhoods (Sey 1998).

In the 1st Development Plan, which came into force in 1963, the state, the informal with the use of public services and the improvement of these areas has begun to formalize a structure. The slums were used in official registries as a type of residence with the Law No. 775 numbered slums which was issued in 1966 and those who could be used in the current situation were 
legitimized (Sey 1998, 288; Tekeli 2009). Thus slum housing has now become identified as one of the forms of presentation produced in Turkey.

In order to reduce the implementation of the slums, the implementation of the Law No. 6188 on Building Construction in 1953, instead of reducing the demand for night-time, has increased the size of the apartment building. With the law, it is proposed to give the empty plots in the authority of municipalities to the non-homeowners. However, this law has not been able to provide any solution for the lower income group to acquire housing, instead it has paved the way for the production of apartment buildings built for migration from the village to the city, or for the middle income groups living in the city (Sey 1998).

Until the 1970s, the small-scale private sector investor established as the applications of the co-operatives were carried out by the municipalities.

In the second incident affecting the post-1950 period, housing the production and presentation format adopted in 1965 in Turkey Flat Ownership Law no. The production of the flats by the cooperatives or private sector entrepreneurs has started to become widespread by law (Tekeli 2009). The land owner who could not build an apartment on his own land with the increase in the construction costs in this period found the solution to be made to the investor by the private sector by giving the investor a certain part of the structure to be made on the plot. In this way, building apartments where private sector entrepreneurs built, where a certain part belongs to the entrepreneur and the other part belongs to the land owner. The private sector investor, who bought land in the city walls in the same way as the build-sell direction, which came into force in 1969, produced housing with the cooperative pair and provided nans with regular payments every month. can produce unit . In this way, the flats, which are implemented as single blocks, have evolved into large-scale settlements where a block was formed by repeating a lot.

With all these legal arrangements, new housing presentation patterns and the introduction of new actors, the speed of urbanization has increased considerably compared to the previous period. The unplanned and sometimes illegal production of the dwellings in the city caused the cities to develop without any plans. On the one hand, it is possible to talk about a city development in which city settlements can be settled or where there are unpredictable squatter settlements, on the one hand, and apartment settlements that can grow and increase in urban centers where there is no place where empty land can be found.

Apart from limited number and small-scale planning and audits, the state has not been able to make sufficient moves to meet the housing demand resulting from intense migration and to establish plans for cities to be developed in this direction. The same can be said for residential architecture and architects. Architectural projects could not be produced which would provide shelter for the new inhabitants of different income and need groups, but also should be designed to determine the direction and form of development of the city.

\subsubsection{After Liberalization, Partial Urbanization, 1980-2000}

After 1980, one of the most important factors affecting all forms of production, including architecture, is the economic crisis in the world and the solutions proposed to be developed against this situation.

In this process, where national economies began to integrate with each other, the nans sector became more dominant than all forms of production, including production. At this point, the development has also follows a parallel path with the world in Turkey. political environment and market conditions in Turkey the management decisions to be included in the economic and financial development approach which has been shaped through on everything. 
The adoption of the liberalization policies of the state administration after 1980 and the private sector of some public rights by the fact that the cities started to be shaped by the laws regulated by a special importance traced. Housing production of public institutions is progressing within the framework of market logic, and the state supports a development based on capital and market economy rather than a public interest in housing practices. In the 1980s, local governments have developed a variety of methods to build their own resources and transfer capital from the outside, and central government often supports these strategies. Turkey enacted in the year 1985 Zoning Law have been changes in the authority of local governments, urban planning decisions are, loss of production is left to the approval and supervision of the municipal authority. In addition to the local authorities, two Mass Housing Laws were enacted in 1981 and 1984 and the establishment of the State Housing Administration, which was to implement this law, started to organize the construction of state housing projects (Türel 1989). The central government continued to produce houses with cooperative partners by working together with local administrations, and also produced mass housing for the middle-income group where Emlak Bank is a banker and investor (Sey 1998; Tekeli 2009). The gaps between the squatter areas in the city wall and the apartment areas in the center are filled with mass housing applications.

All these modes of production show that the housing capital remains under the dominance of financial production. The relationship between the housing demand and demand has changed the definition of the commodity. The housing demand faced by the architect now comes from large-scale investors rather than individual users. The houses have been designed in accordance with the investor requests instead of user needs and requests.

Instead of the value of use, it is expected that the architect expects the architects to design featured designs that are expected to be valid in the market or attract high income groups. In other words, the housing structure that will be designed reflects the needs and desires of the user and the housing has changed with the fact that the house is perceived as a property that can be entangled in the market economy.

The design of the house has become a marketing value that is used to distinguish the structure from its peers and stand out in the production and sales stages, independent of the user. In this period, the value of architecture, which has been achieved with its own internal dynamics, has begun to be explained only by the value of the result of architecture.

In the post-80 period, different forms of formation emerged regionally in cities as a result of supporting the private sector investor by the state in the production of housing, distributing the central authority system and transferring the powers of the authorities to the local administrations. Instead of planning the city as a whole, it is the most important characteristic of the period to be divided into pieces and each piece is planned by a different actor on the basis of parcels.

The plurality of plans developed by the various actors and the contradictions between the urban parts of the city have been invaded by uncontrolled housing settlements in this period.

\subsubsection{Post-earthquake urban transformation, after 2000}

After 2000, housing starts and the capitalist neo-liberal approach in the development of the 80 starters to have a say in all sectors after a lot in Turkey and has been shaped by the global economy.

The central governments are trying to provide their connections to the global economy through the cities, especially the urban centers, as it has been revealed in the literature (Gordon vd 2004; Keyder 2005; Keyder 1999; McGuirk 2005; Salet 2006). In the 80s, the global capital, which discovered the capacity of the house to appeal to large audiences and turn into easy 
liquidity, continued to invest in housing in the 2000s. National, international nans organizations, banks or large-scale investors have started to produce houses by establishing joint partnerships as well as participating in housing production on their own and raising the scale of production above the housing presentation forms in previous periods.

However, unlike the previous period, capital groups apply these houses at important central points within the city, thus trying to have a share in the regions that provide value increase. changes in Turkey's internal dynamics are well advanced in this way supports largescale production. Especially after the 1999 Gölcük earthquake, the situation of the existing housing stock started to be questioned and the renewal of this inventory has emerged. The project-oriented renewal process, in which the old settlements and squatter districts in the 80s started to migrate, moved to an urban scale after the earthquake, so that the residential settlements in the center began to be reproduced through the concepts of urban renewal and urban transformation.

The economic sector led by the transnational capitalist class has focused on housing production on large urban parts discharged by the concept of transformation. There are basically two reasons for this orientation. The first of these is to address a wide audience in terms of the capacity of the house to be consumed, and thus to turn into liquids more quickly and easily.

The second reason is that housing applications are suitable for reproduction by combining them with various trade and service units. For this reason, the first issue the investor focused on obtaining capital has been the production of housing.

Housing presentation styles developed during this period can be defined through the housing produced in the work area of TOKI, which dominated the sector in the housing production in the 2000s. The high density housing residences, which are produced under the social housing heading and which are mostly from the city center, formed by repeating blocks formed by a single type of plan scheme, are the first of the housing presentation forms. In fact, these apartment buildings, which were produced both in and outside of the city in the previous periods, have increased with the increase of the mass production technologies and experience in 2000s, and it has been a form applied by mass housing administration and local governments.

These settlements, which contain a large number of units, are intended to accommodate the lower-income group who migrated to the city and produced informal residences in previous periods. However, the users of these dwellings are mostly the lower income group living in urban slums in the city center through urban transformation.

Real estate investment forms another, in a single block, mostly in a city center, in a more limited area than a mixed function structure multi-storey residences. Due to the space limitation in the residences, the units are small and leasable. In addition, these structures are the most integrated with the sheltering function of the service sector. These buildings, which give shelter function in a hotel service rather than a residence, are defined as secure sites positioned vertically in the city center (Danış ve Perouse 2005). The user of the buildings is usually the upper income group who will stay in the city for a certain period of time or work in the city center and do not want to break away from the center (Bilgin 2006). The integrity of the planning is lost due to the parcel-based decisions applied for the mixed settlements where the different trade and service units are designed together with the housing units. The settlements that are constantly changing and transforming within the city make the layout of the city's macro form unobtainable and lead to the continuous movement of different socioeconomic groups. 


\section{REFORM CRITERIA IN HOUSING SYSTEM}

The restructuring and operation of the Housing Development Administration since 2003 and the amendments and amendments in the Law No. 5582 on the Amendment of Various Laws on the Housing Finance System, which came into force after being published in the Official Gazette on 6 March 2007, launching, and then commencement of the demolition production activities foreseen by the Law No. 6306 on Transformation of Areas Under Disaster Risk, which came into force after being published in the Official Gazette on May 31, 2012, can be defined as the solution tools of the state in the struggle against the housing problem, it has come. To determine how the state's political instruments evolved in the historical perspective in overcoming the housing problem and to discuss and interpret the political choices applied in different periods in a comparative manner constitute the reason for writing this article.

The fact that the housing sector has a structural character that can create depressions due to the new identity of the housing sector in the paradigm shift that started with a central function in the world economies, the fact that the global economic crisis can be caused even when the housing resources are not used carefully. This fact raises the question of what should be done if it is not possible to make a home by lending everyone by means of the state by providing sufficient financial means to each household by making it possible for them to be able to become a homeowner. Housing problem can be perceived differently in terms of individual, state, producer and investor. However, the part of this phenomenon that concerns the state is the social dimension of the problem. From this point of view, it is considered as a social definition of housing problem whether it is possible to produce a certain standard of housing and distribute it to all segments of society (Tekeli, 1996). If this definition will be opened further; different needs and demands (demand) segments in the sense of housing in the context of the market mechanism to meet the variety of types of presentation and supply opportunities within the framework of the supply, and the need to remove and reduce the constraints of the state in this regard as far as possible to create the scope of this problem constitutes the scope of this problem.

\section{DEVELOPMENT INDICATORS IN THE HOUSING SECTOR}

For the solution of the housing problem, all the legal and operational measures taken by the state and the priorities determined are called housing policy (Keleş, 2010). If the housing policy concept is to be examined, how the housing becomes a field of policy-making, how housing policies manifest in developed and underdeveloped countries or the problems encountered in its formation and performance can be studied and explored separately. But the only discussion of public interest is the question of how a successful housing policy should be designed.

According to Keles (2010), three basic principles should be adhered to when building a successful housing policy. The first of these principles is the principle of the appropriateness of housing policy and development objectives. This appropriateness is necessary to establish the balance between the housing needs of the masses and economic opportunities. Second, it is the principle of settlement policy and the country's urban and regional development policies. This numbness arises from the fact that housing policy is only related to the solution of the other problems of the natural and structured environment in which the house is located rather than meeting the housing needs, and that the housing cannot be ignored in the sense of the balance of industrialization and urbanization in the regional distribution. The third principle is that housing policy must have priorities. These priorities can be determined by targeting specific social classes and clusters for the needy, targeting citizens at a certain level of income and targeting specific housing standards or production costs. 
A housing policy that is designed with these principles in mind; Financial Interventions to be carried out on housing investments, taxes, loans, housing purchase methods and similar areas, rent control and condominium applications, legal interventions to be carried out on various legal restrictions and incentives and housing standards, housing production types, construction methods and building materials technical interventions.

Housing development, which is one of the most important implementation tools of housing policy, is the ability of this fund to be transferred to the buyers who are in need of funds and who are willing to borrow in order to buy / make their own home from those with surplus funds. It is indispensable for those who need a successful housing finance to enable long-term borrowing. Because housing is an expensive commodity, which seriously pushes the budget of households. In the absence of long-term borrowing, the acquisition of housing in the short term is often impossible. There is a very clear link between the housing and housing development in the country. The typologies and quality of housing use in a country are the product of success or failure of housing financing in many places.

Housing problems, housing policy and examine engagaments held in Turkey on a private housing finance field are reached some conclusions. The first one is the fact that the housing problem is a dynamic structure and may vary periodically in Turkey as it is in the world due to changes in demographic structure, stock depreciation and migration (Tekeli,1996), It is stated that the solution methods of the multi-functional structure of the house for a period in the housing problem can be a problem for later periods. Second, it is compulsory that the issue of housing as an economic asset increases with the globalization of the world, and that it is necessary to address this issue more carefully in countries that are in the process of transition to global economic integration. Third, the rapid population growth in Turkey (albeit with a relatively slow) will continue in the coming 20-year period together with urbanization, especially the aging of the stocks that make up the majority mania apartment blocks began in 1950-1960's year, worn with together will increase the destruction, the decline in household size, age pyramid the fact that there is a large number of young people in the age of marriage, the willingness of the state to get rid of the shanty living areas of the slums, and the fact that the ease of buying, renting and renting means that the housing market will grow and grow beyond the doubt in the coming years. These determinations related to the housing problem have resulted in more production, infrastructure, support and incentives, more measures and arrangements by the state in the following years. It may be deduced that this issue will need to be more focused. When determining the housing policy; SIS (today TSI) and TOKI's supervision, prepared as a condition of a grant obtained from the World Bank Turkey Housing Research 1999 is that none of the conditions in the present study findings in the day a large extent today, the main issues that need to be searched for solutions in building retains its validity and policy these findings are still noticed. According to the results of the research; Compared to many countries of the construction costs in Turkey, there has not been a shift away from efficiency in the functioning of the construction industry due to the low. In terms of efficiency in distribution, there are problems in the provision of housing to low-income people. A substantial share of the population in cities does not have the financial means to acquire housing from the licensed stock. Considering the results of the housing market as a whole, it is not possible to talk about the production distribution efficiency. Even today, in small cities, unlicensed housing construction continues in the country. It is understood that the products which are differentiated to meet all kinds of housing needs could not be offered with the licensed housing presentation.

These results are problem areas that need to be built on top of the housing policy in Turkey when combined Turel (2002) describes as follows: 
"The overall performance of the housing sector in Turkey, the affordability of housing, the share of total housing stock of unlicensed Despite well when evaluated by the number of manufactured housing is a big problem compared to the requirements despite the presence of."

It was mentioned earlier that the housing problem could have a different meaning for everyone. Housing policy, unlike housing problem, is the concern of the state alone. Because, it is not very rational to expect that national equality is effectively owned by individuals and producers in the sense of residential development. The most important issue that can be considered here is the fact that the housing policy will never be considered independent from the economic, political and social conjuncture of the period in which it is valid. For example; The idea that the latest development plans should be introduced as a national system for the promotion of housing, at least until the present time, the opinion that the private sector could be included as much as possible to the problem of financing on the back of the public has been the driving force of the recent political quests.

If the housing financing is continued; The first determination is that the housingbuilding structure is no longer a public function and is abandoned to the market order. This situation is negative in terms of not only the social conditions of the market and the sustainability of the social order, although it is positive for the public to save itself financially from the housing projection, which has become a futile effort with the funds it has overtook over time.

Secondly, it is understood that there is no desired improvement in the economic problem of housing in the metropolises, especially in metropolises. This situation shows that the level of access to housing continues to open between the social boundaries in the context of access to and use, given that the level of public access cannot meet the real requirement, although the public continues to produce housing intensively for the needy.

Third, in need of new housing financing system will be unable to reel sectors though, it is the fact that it will continue to grow in Turkey. This growth will bring many benefits to the economy as well as means to raise the risks it contains with itself. Although the ones who are included in the system to be the owner of the first house have been freed from the rent load, it is seen that even the top income earners can only borrow the budget evenly. Considering that the number of individuals borrowed for housing will increase in the coming years, it will be another subject worthy of consideration from the sociological point of view that the Turkish people who are not accustomed to living in the long-term borrower will adapt to the fall in the standard of living which will be caused by the other expenditures that they have to cut down on their housing.

Another important finding that can be said at this point is that there has been a general increase in housing yachts in periods when mortgages and similar political choices are intensively applied to increase the ownership of housing. This situation has a difficult effect on the fact that the segments of the society other than the upper income groups have housing other than the houses addressed by the system. In other words, although this system encourages the production of housing and even residential areas that will serve the mortgage market, it is impossible for the society to respond to the needs and desires of the lower and middle income groups, and it can be said that these individuals indirectly undermine their accessibility to the housing without the existence of the system.

According to Balaban (2007), it is not correct to expect that this system, which provides the expected profitability at low risk, will yield results in the form of a social policy. The actors of the system are trying to protect and develop their positions within the market by not including the solution to the social dimension of the housing problem, but by including the people and 
the houses that meet their own criteria in the system. Another statement of this situation is that the orientation in the implementation of this system is not the housing need but the demand for housing. In fact, housing and most tragic way to the bottom and the middle-income households felt by facilitating access to housing for high-income earners in Turkey and that there is an accelerator-based political orientation of the housing problem is quite contradictory. Ensuring that access to housing of all segments of society in terms of state Whereas the housing problem, if housing policy in this purpose to ensure the realization of the manufacturing and distribution activities of legal and remembered that taking the issue of administrative measures, remains a comprehensive and functional housing policy at the desired level in Turkey, it can be concluded that there is in force fiction. At this point, if the housing-development system is perceived only as one of the tools that the state can use in combating the housing problem, rather than being seen as a solution of the housing problem alone, it can only be meaningful beyond the popular debates and commercial expectations.

The periodization of housing policy throughout the history of the country, which was characterized by Keleş (2010) in five periods prior to the 2000s, allows the identification of the sixth period, which is a new era, with some developments in the country since 2003.

The signatures of this sixth period, which started with the transfer of all powers of the Undersecretariat of Housing, which was established in 2001 as a roof institution in order to determine and implement the land and housing policies together in 2001, abandoned the role of TOKI as a conventional finance institution, and continued to do so with the weakening of the country's co-operatives into the background, with the entry into force of the Law No. 5582 in 2007 , when the state left the housing development area to the private sector. This period can be mentioned as a neo-liberal period or a special finance period or by another name.

With this period, politically changing and reflected on the society; Instead of the upper middle, middle and lower middle income groups, which are predominantly used by the cooperatives supported by the state's limited facilities, which means that the subsidies are mainly distributed to these social sectors, social housing production through the use of subsidies is a method of benefiting. In other words; subsidizing the body part of the economic layers in the sense of housing.

This new period is also parallel to the execution of the same political power, which began with the change of power and has been carrying out this task ever since. It is true that the policies implemented in this process resulted in many arrangements that enabled the formation of this new period and that these arrangements reflect the character of the period, but it would not be right to argue that the new perception and understanding occurred only from the practices of political power. It should not be forgotten that the financialization of the economy in our country and the shaping of public policies accordingly are similar in many world countries as a trend parallel to global financialization. It should be said that the philosophy behind the change in the described housing policies is the concept of new development which supports the fragile sectors which are the most risky sectors with the most progressive sectors instead of the fairness of the resource distribution between the economic sectors.

On the other hand, the fact that the state's choice has changed in this way is open to criticism. Because the subsidies distributed between the old and the income groups were clearly more fair. This fair approach allows middle and lower middle groups to pass through the lower segments of leased housing or property, allowing the market to close more speculative movements in a sense, contributing more to ensuring the stability of yachts, and does not increase the opportunities of the highest number of income holders in housing access. in this way, in a sense, it was able to prevent social segregation through housing. The new procedure has opened the way for the higher income earners who have more advantages compared to other 
sectors in order to reach the house more quickly and easily. Moreover, although the level of social housing production is higher than in the past, it is a reality that it is very small compared to the absolute need in the social layer it targets. This also means that lucky people among have been formed among the state and lower income. Here is a phrase of lucky cuts; it is a situation in which the poor household, who accesses the social housing provided by the state in a way, is sitting in her own house and this situation creates a serious contrast with the fact that the relative income in the neighborhood next to her is sitting in the rent of higher middle level civil servants or family of tradesmen.

It cannot be overlooked that this new approach gives more opportunities to the financial development of capital companies than before. Hundreds of housing production jobs are made by the state each year, and valuable land in high areas is handed over to the sellers for the purpose of housing production. The ability of the Turkish construction industry to produce qualified housing quickly when it is provided is truly admirable. However, especially in recent years, the statements made by the bosses of the capital companies stated that there is an abundance of housing in the market and that more housing has been produced recently. This is not true. This is a result of the applications that come with the new understanding. There are millions of people in the society who live in unqualified, unhealthy and illegal housing. The truth of this complaint, expressed by the capital companies, should be: a we cannot find buyers for the houses we produce capital. Because the yachts of the dwellings produced are well above the payment capabilities of the real need segments. This situation is valid not only for the houses produced by the capital companies but also for the houses produced by TOKI personally. So, it can be argued that this new political understanding creates a presentation requirement mismatch. This must be done in order to avoid incompatibility; by ensuring effective demand organization, and shaping the presentation forms accordingly. As a matter of fact, considering the fact that the best structure that can fulfill this function is cooperatives, the disadvantage of abandoning the old method is seen.

The new understanding is open to criticism from an administrative perspective. The fact that a single institution can plan and sell public lands without supervision of its own in any way, and the fact that it can be used in the favor of its market maker feature with the principle of questionability of any kind of operation of the execution seems incompatible with the principle of providing commercial justice. Housing policy proposals that reduce direct budget revenues or increase budget expenditures are no longer needed in the world in terms of achieving economic stability and reducing risks in the budget. As a matter of fact, it was for this reason that TOKI's income and expenses were excluded from the budget. It is also unacceptable, however, that a state institution whose financial structure is autonomous is not subject to any control. In addition, the fact that the area was left to the responsibility of a single institution with the absence of housing in the final development plan was also registered. This development can be considered as an image of the political freedom that the new understanding mentioned above makes.

The reform of the private sector to mediate the finance has indirect benefits such as the financial benefits, the impact on housing production, the mobilization of the construction industry, the establishment of new projects and the increase in employment. It is expected that investors, consumers, industrialists and service areas such as insurance will benefit from these opportunities and the state will be strengthened by the taxes it will receive from these activities. However, it has been understood that the real need segments of this reform do not have any contribution to the problem of payment of the housing and therefore do not give any result as a social policy. It is evident that the system remains an innovation that does not have a function other than the poor segment of society, but has the potential to be a new financial instrument and to produce other new financial instruments. 
In spite of all these, in this period, the inquiries about the determination and execution of housing policy are not made by the authorities. For some, the state should completely abandon its housing production, and should assume the role of former procedural financing. According to some, TOKI should be a financial institution but, contrary to the known, it should be an institution that buys and sells the funds used in the private market, not even lending, but even guarantees the issuance of securities. Some should continue to increase their current activity.

It is observed that the private financing practice in the new period does not serve the needs of both the supplier and the beneficiary, and the intermediary, in addition to this, enables them to earn more. The main question should be to question how, despite all the criticisms made, this new opportunity can contribute to the socially oriented goals. This issue will gain meaning when evaluated with the question of what will be the institutional role of the state. At this point, the question 'Since the new housing can not reach the real need segments, since the state cannot meet the absolute needs with social housing production alone, so what is to be done comes up.

Experience shows that neither only the upper and lower earners will be benefiting from the subsidies presented in some way, nor by leaving the rest of the middle cluster earners to support others effectively. It is necessary to get rid of the binary structure formed in the form of unsupported ones. Therefore, it will be the most effective political fiction to identify the priority of each different sector individually and to support the households as much as possible to the extent that unfair distribution of income makes it difficult for them to reach the house.

For the formation and implementation of the said effective political fiction, localization of housing policies is essential and should be the first step. Legal and administrative arrangements should be made for the realization of the housing programs that municipalities can implement primarily for those with low incomes, cheap house representation programs and project and license support programs should be implemented especially for the households to produce their own houses. These programs can be operated by the governorships, formerly known as the announcement of the shanty districts, as the social housing area, by building the infrastructure and plans of the municipality and selling the small parcels that they have created to the ones who want to produce housing for their own use. In fact, it is possible to achieve various local subsidies, such as municipalities providing free architectural and engineering projects to these households and providing housing and building permits for low fees.

The second important issue that needs to be achieved outside of decentralization is the acquisition of housing cooperatives as a powerful political instrument. It will be very difficult to distribute subsidies to households in the middle-income group, unless there is a gain. The reemergence of cooperatives in the country is primarily increasing the reliability and effectiveness of the cooperative. For this purpose, the cooperative needs to be reformed for the true purpose of getting rid of the pretentious style of presentation. The basic principle of this reform should be the financial, legal and technical strict supervision of the co-operative.

Models can be developed to achieve this. In addition, to prevent overcrowding of the number of members of the co-operative to be limited to the upper membership limit, the cooperative management can not consist of people other than members, cooperatives can do construction on their own land, but the co-operative center troops to increase the effectiveness of the member cooperatives and public-supported co-operative work within the scope of state procurement law mandatory measures such as the fact that these organizations will be directed back to their real goals and that their serious support by the state will make sense. If this reform is achieved, it may be possible for the cooperative and its members to benefit from the loans within the scope of the new housing financing. 
A third variety should be on increasing the supply of cheap rental housing. So far, neither the state nor the private sector nor the co-operative has ever stopped the country, and this issue will provide a serious opportunity for those who have difficulty in accessing qualified housing before the transition. This type of presentation, which can be developed for groups such as newly married couples, students, migrants or temporary residents who are not yet able to own a home in the framework of their needs, will provide significant relief in terms of improving the housing conditions of the community. As capital companies act with great profit motives, they are constantly turning to high quality housing production. However, there is no restriction for the real estate investment trusts that produce and earn capital by renting real estates on their balance sheet and renting them for the needy. Through these companies, the production of houses that meet the basic standard of living below a certain rent limit can be encouraged. The same applies to municipalities and cooperatives.

\section{CONCLUSION}

Although the construction sector has a significant place in the formation of fixed capital since the foundation years of the Republic, there are two historical breakpoints that bring about the acceleration of the sector: the 1950s and the transformations, especially in the second half of the 1990s and the transformations in the economic policy in the 1980s, seen in the 2000s. The importance of the sector arises rather than its place in the national income, considering its backward and forward links with many sectors.

As the public and private housing policies pursued since the beginning of the republic encouraged the production of upper-middle and upper-class housing, the housing deficit of the lower and lower-middle classes continues in this housing surplus in the conditions of deterioration in income distribution. Therefore, the housing deficit or surplus cannot be mentioned for all social sectors. The housing problem is class.

If the housing financing is continued; The first determination is that the housingbuilding structure is no longer a public function and is abandoned to the market order. This situation is negative in terms of not only the social conditions of the market and the sustainability of the social order, although it is positive for the public to save itself financially from the housing projection, which has become a futile effort with the funds it has overtook over time.

Secondly, it is understood that there is no desired improvement in the economic problem of housing in the metropolises, especially in metropolises. This situation shows that the level of access to housing continues to open between the social boundaries in the context of access to and use, given that the level of public access cannot meet the real requirement, although the public continues to produce housing intensively for the needy.

Third, in need of new housing financing system will be unable to reel sectors though, it is the fact that it will continue to grow in Turkey. This growth will bring many benefits to the economy as well as means to raise the risks it contains with itself. Although the ones who are included in the system to be the owner of the first house have been freed from the rent load, it is seen that even the top income earners can only borrow the budget evenly. Considering that the number of individuals borrowed for housing will increase in the coming years, it will be another subject worthy of consideration from the sociological point of view that the Turkish people who are not accustomed to living in the long-term borrower will adapt to the fall in the standard of living which will be caused by the other expenditures that they have to cut down on their housing.

There are three basic principles should be adhered to when building a successful housing policy. The first of these principles is the principle of the appropriateness of housing policy and 
development objectives. This appropriateness is necessary to establish the balance between the housing needs of the masses and economic opportunities. Second, it is the principle of settlement policy and the country's urban and regional development policies. This numbness arises from the fact that housing policy is only related to the solution of the other problems of the natural and structured environment in which the house is located rather than meeting the housing needs, and that the housing cannot be ignored in the sense of the balance of industrialization and urbanization in the regional distribution. The third principle is that housing policy must have priorities.

The two laws enacted in 1948 contain provisions to enable municipalities to deal with the housing problem. The first of these is Law No. 5218. As stated in the commission in the Assembly, it is not expected to find a solution to the housing problem of the country expected from this regulation; The aim of the law is to make the existing slums within the municipal boundaries a legal situation. This is a kind of slum amnesty law, the examples of which increased in later periods. The law introduces the rule of rehabilitating slums that are suitable for rehabilitation, and for those who are not eligible to accommodate slum owners.

Within the framework of the conditions stipulated by the law, the treasury land occupied by the slums is transferred to the municipality, and in this way, cheaply produced lands are allocated to slum owners or those who want to build a house. The second is the Law on Encouragement of Building Construction No. 5228. With this law, the task of producing land for housing over municipalities has been extended to cover all Treasury lands within the municipal boundaries, whether or not the slum area.

In addition, it has been made possible to allocate the lands to cooperatives as well as individuals. Tax immunity was introduced and credit facilities were increased. Both laws have kept the ownership of the cheap land produced in the public sector, instead of going to the leasing route and ensured that they are transferred to private ownership.

In the Constitution of 1924, besides the rule that the house was protected against all kinds of attacks (m. 71), the immunity of the house was also accepted (m. 76). However, a provision regulating the right to shelter other than these articles on personal rights was not included in this constitution. The right to housing was included in the 1961 Constitution. However, the right to housing is regulated under the heading "right to health". The Constitution continued the traditional understanding of that period, which put hosting in the context of the right to health.

In terms of Article 49 of the Constitution, the need for housing will have to be met as a condition to lead a life in physical and mental health. According to this article, the state is responsible for taking necessary measures to meet the housing needs of poor and low-income families in accordance with their health conditions. This emphasis on poor and low-income families is reflected in the item justification as "people who do not have the minimum possibilities of accommodation like a human being", but this is in fact contradictory, as stated in the commission studies, with the expression "the greatest service is to make the low-income citizen a homeowner". It was reviewed.

Because the statement in the Constitution does not mean that everyone has a property that is their property, but that the need for housing is met. The only and most effective way of meeting accommodation needs is not property housing. If the housing policy tries to offer the property as a solution for the poor, who cannot afford to buy property, it becomes impossible to address the housing problem. As a matter of fact, with the article on the Constitution of 1961 Constitution, we see that the house started to be handled as a public service in the early 1960 s. 
The First Five-Year Development Plan, which includes the years 1963-1967, reveals the state of the houses in the early 1960s. Accordingly, thirty percent of the residences in the cities are unable to sit. Thirty percent of the population living in Ankara, Istanbul and Izmir are housed in one-room houses. about one person per room falling in Western Europe, which fell 2.5 persons per room in Turkey.

These figures can give an idea to demonstrate to what extent the housing policy implemented until the 1980s has accomplished ease of land credits, which is one of the two important pillars of the land. While the share of loans granted to the home in bank loans was only 3.1 percent in 1972, it decreased further over the years and decreased to 1.4 in 1977.

The 1982 Constitution sets yet another rule not found in the 1961 Constitution: The state supports mass housing initiatives. Thanks to this rule, state support for the construction of mass housing is an important policy tool in the face of the rapidly growing housing deficit. Laws on public housing have been enacted and legal arrangements have been made in this regard. However, in practice, some distorted results may have occurred, as we will discuss shortly.

According to 2000 data, there are a little on the household 15 million in Turkey, while the owner of the house where they lived in two-thirds of tenants, the rest living in public housing, includes households as sitting in lease payments in someone else's home. 87 percent of households living in villages live in their own homes. The tenancy rate in the city centers is 33 percent. According to TURKSTAT's 2007 data, the proportion of hosts decreased by 8 percent in seven years to 60 percent.

Based on these data, one can argue that a housing policy devoted to buying property is an appropriate and valid policy, with the following findings: It is stated that the price of affordable housing should be below 30,000 TL, and the lowest price of new housing projects put up for sale in 2005 varied between 60,000-90,000 TL. Low-income households constitute a 21 percent slice, and the price of affordable housing should not exceed 45,000 TL 


\section{REFERENCES}

ALEXANDER, C., NEIS, H., ANNINOU, A. and KING, I. (1987), A New Theory of Urban Design, New York: Oxford University Press.

ALTMAN, I. and ZUBE, E.H. (1989), Public Spaces and Places, New York: Plenum Press.

APPLEYARD, D. and LINTELL, M. (1972), The environmental quality of city streets: The residents' viewpoint, American Institute of Planners Journal, 38: 84-101.

ARTAN, T. (1989), Architecture as a theater of life: Profile of the eighteenth century

BERGER, A. (2000) Streets and public spaces of Constantinople, Dumbarton Oaks Papers, 54 : $161-172$.

BOSPHORUS, U. and BASSETT, S.G. (1991) The antiquities in the Hippodrome of Constantinople, Dumbarton Oaks Papers, 45: 87-96.

BROADBENT, G. (1990), Emerging Concepts in Urban Space Design, London: Van Nostrand Reinhold. Unpublished Ph.D. thesis, MIT, Cambridge, MA.

CLAVIO, R.G. (1970), Narratives of the Embassy of Ruy Gonzalesdes Clavio to the Court of Timur of Semerkant AD. 1403-6, New York: But Frankline.

CORBETT, N. (2004), Transforming Cities: Revival in the Square, London: RIBA Enterprises Ltd. Publishing.

CRAIG-SMITH, S. J. and FAGENCE, M. (1995), Recreation and Tourism as a Catalyst for Urban Waterfront Redevelop- ment: An International Survey, Westport, CT: Praeger.

DARK, K. R. (2004), Houses, streets and shops in Byzantine Constantinople from the fifth to the twelfth centuries, Journal of Medieval History, 30(2): 83-107.

DE AMICIS, E. (2005), Constantinople, S. Parkin (Trans.), London: Hesperus Press.

DOKMECI, V. and BERKOZ, L. (1994), Transformation of Istanbul from a monocentric to a polycentric city, European Planning Studies, 2(2): 193-205.

ERGUN, N. (2004), Gentrification in Istanbul, Cities, 21(5): 391-405.

ETHINGTON, P. J. (1994), The Public City, Cambridge: Cambridge University Press.

GEHL, J. (1987), Life Between Buildings: Using public spaces, New York: Van Nostrand Reinhold.

GOHEEN, P. G. (1998), Public space and the geography of the modern city, Progress in Human Geography, 22(4): 479-496.

GULERSOY, C. (1994), Kapalicarsi, Istanbul Ansiklopedisi, 4: 422-432.

HAMADEH, S. (2007), Public spaces and the garden culture of Istanbul in the eighteenth century, in: AKSEN, A. H. \& D. GOFFMAN (Eds), The Early Modern Ottomans: Remapping the Empire, Cambridge: Cambridge Press.

KELEŞ, R., (2010), Kentleşme Politikası, Ankara: İmge Kitabevi

LOW, S. (1996), Spatializing culture: The social production and social construction of public space in Costa Rica, American Ethnologist, 23(4): 861-879.

LYNCH, K. (1981), Good City Form, Cambridge, MA: MIT Press.

MADANIPOUR, A. (2003), Public and Private Spaces of the City, London: Routledge. 
ROSENTHAL, S. T. (1980), The Politic of Dependency: Urban Reform in Istanbul, Westport, CT: Greenwood Press).

SAIRINEN, R. and KUMPULAINEN, S. (2006), Assessing social impacts in urban waterfront regeneration, Environmental Impact Assessment Review, 26(1): 120-135

TAPAN, M., SEY, Y. ve TEKELİ, İ., (1998), 75 Yılda Değişen Kent ve Mimarlık, İstanbul: Türkiye Ekonomik ve Toplumsal Tarih Vakfi

TEKELİ, İ. (1982), Türkiye'de Kentleşme Yazıları, Turhan Kitabevi: Ankara

TÜREL, O., BORATAV, K., and YELDAN, E. (1996), Dilemmas of structural adjustment and environmental policies under instability: Post-1980 Turkey. World Development 24(2February): $373-393$

WHYTE, W.H. (1980), The Social Life of Small Urban Spaces, Washington, DC: Conservation Foundation.

ZACHARIAS, J., STATHOPOULOS, T. and WU, H. (2004) Spatial behavior in San Francisco's Plazas, Environment and Behavior, 36(5): 638-658.

ZUCKER, P. (1959), Town and Square: From the Agora to the Village Green, New York: Columbia University Press. 